\title{
INDIVIDUALISM AND REALISM"
}

\author{
Gaston Gavet \\ Professor of Law, University of Paris, France
}

NATIONAL SOVEREIGNTY

"Many others have said that the modern notion of the sovereignty of the State identified with the personified nation was a historical product. They were right. But they affirm that progress has been accomplished, that by a prolonged effort we have learned to detach the notion of sovereignty from the notion of personal power." Now, that is inaccurate.

"Far from the notion of national sovereignty constituting a sort of reaction against the idea of princely sovereignty, it is on the contrary the continuation and development thereof.... . The revolutionary legislator was himself unconsciously profoundly penetrated by monarchical ideas; he limited himself to substituting the nation for the king and in constructing national sovereignty upon the model of royal sovereignty. The notion of sovereignty of the nation is thus merely a survival of the conception of the princely state which was itself a product of the feudal régime. This personification of the State, this affirmation of a national sovereignty is only the false adaptation to the modern world of a decayed idea. By denying the personality of the State, the sovereignty, we disengage ourselves from a valueless and meaningless anthropomorphism, and we reject absolutely all the remaining balance of the feudal and princely conception of the State."8

To sum up, "this notion of sovereignty is merely the survival of a distant past. We must endeavor to establish that point." Duguit proceeds to do this by a narration.

That a man like Duguit could write the above exposition is indeed proof of the terrible difficulty which abridgment in history presents. ${ }^{\text {? }}$

${ }^{3}$ Continued from (Ig20) 29 Yale Law Jourana, 538.

I Duguit, op. cit., 376.

'We are attached to our eminent colleague by too long and cordial a friendship and we recognize in his work a too striking merit to yield here to the poor pleasure of criticism. But after all it is we, the individualists, whom he attacks, and without consideration; we must therefore defend ourselves. Let Leon Duguit himself read again with us phrase by phrase the indictment which he believes condemns us.

(r) "The king as an individual is the owner of his rights of power." Duguit, $o p$. cit., 328. Now the legists do not tire of defending the $\mathrm{King}$ (capital $\mathrm{K}$ if you please) against the king (small $\mathbf{k}$ ), that is to say, against the human individual who incarnates Royalty and it is to the first that the rights belong of which they tell us.

(2) "Is the owner of his rights of power." See the text.

(3) "The individual king is a person." I see nothing inconvenient in that. "Rights of sovereignty are an emanation of his will which has a real existence." Not at all I His rights are the product of custom, which, in giving a monarchial form to the government of France also creates the "laws of the kingdom" which 
Here are certain pages of which almost every line violates our conception. On the rails of our railroads, at crossings which must not be passed before a certain time, people place torpedoes which explode under the wheels of the locomotive. On the route of Duguit, all the philosophy of our history, falling to pieces, constitutes a rolling fire.

Among all these assaults upon truth we point out only those which constitute his argument. They may be grouped under the three following ideas: (I) the feudal king is the owner of the kingdom

establish the modalities of government and the somewhat limited power of the royal will

(4) "The modern transformation consists .. ." See text.

(5) "From the legal point of view the feudal regime is characterized in particular by this fact that the relations of the governing to the governed are not considered as relations of superiors to inferiors..." Then how can this feudal hierarchy of which we are told exist? Since the word "vassal" commonly has two meanings, if Duguit understands by vassals all individuals subjected to the administration of lords, serfs, mere freemen, etc., these are indeed the governed; but it is difficult not to see in them inferiors bound otherwise than by contract; and if by vassals he means the holders of fiefs granted by the lord they are not the governed. See the text.

(6) "Not like the relation of superior to inferior but like the relation of two contractors. A series of contracts imposing reciprocal obligations upon diverse members of the feudal hierarchy." First, between relations of superior to inferior and contractual relations there is no opposition. The contract may even create serfdom, even slavery at the beginning of the-feudal epoch. But what "series of contracts" does he mean? Not copyholds, (accensements) for they do not create reciprocal obligations, and those that they create passively on the part of the copyholder are propter rem and do not place persons in a hierarchy. At the source of every fief there is indeed a contract which suffices forever. The taking of the oath and homage, which is renewed on each change of vassel (or lord) cannot be refused by the lord and is not a contract. Would you speak with historians of that kind of contract already mentioned, by which the lord and the people would reciprocally promise, the one protection, the other submission and dues? This is pretty and attractive but a phantasy.

(7) "The hierarchy of land corresponds to the hierarchy of persons." What hierarchy of persons does he mean? The king of France, the suzerain of a certain minor lord, might be his vassal for a certain sub-fief without an anti-feudal purely monarchical rule. Two feoffees (holders of fiefs) might equally be lords and vassals, the one of the other. What there is of personal hierarchy in feudal society is not feudal; reflection will quickly induce recognition of this fact. The source of it is in the Carolingian centralization and in ancient hegemonies of distant origin.

(8) "The king is only a lord like any other." See text.

(9) " . . - exercising over his vassals certain rights by virtue of the real contract which is attached to this feudal property." See text.

(I0) "The princely State succeeds the feudal regime. Kings and their legists construct the political and sovereign power of the prince." "See text.

(II) "Their legists." It seems to be thought that they evolve their theories on command. This may be possible in the case of some; but to take them en masse is singularly depreciating. their role to make of them mere employees of the king who in reality had to be thankful to the feudists.

(12) "One invokes above all this principle of feudal right that the king's mission is to cause the reign of justice, to give the public peace." If this phrase were not the utterance of $M$. Duguit it would not be taken very seriously. Is this mission of the public power a "feudal" principle?

(13) "The right of feudal justice becomes.a royal right which extends beyond vassals over all individuals." $M$. Duguit evidently means not feudal justice but seignorial justice. The idea does not become much less inaccurate. See the text.

Perhaps it is better to stop here. We have read only a page and a half in 20 . We recognize moreover that others depart less often from what appears to us to be the truth. 
as a fief; (2) the monarchical king retains the right of the feudal king; (3) the revolution only transfers to the nation the rights of the king.

(I) "At the origin of the feudal period the king is only a lord like any other, the owner of his fief, exercising over his vassals certain rights by virtue of the real contract which is attached to that feudal property." Frankly, I do not understand the meaning of this sentence. Infeudation is a double operation. It comprises first the act by which a man makes himself the "man" of a lord and is received as such; (2) the act by which in recompense the lord grants a fief. Little by little the chronological order, if we may so speak of these two acts, was reversed, but both always subsist at the basis of the operation. The first creates actively certain rights of the infeudant over his man, but they are not "real"; the second, which alone could perhaps receive that designation, leaves to the lord certain rights over the fief, such as escheat, etc., but does not create obligations. Those which do arise come from the taking of the oath and homage.

All the formulae of 'Duguit doubtless shelter themselves behind controvertible ideas, but this matters little. What he wishes to be emphasized is this: "The king is a lord like any other and the rights of a lord are patrimonial property rights." This we would contest. The king is not a lord like any other, for if he were there is no kingdom, a lord being nothing beyond the territorial limits of what he has kept for himself or infeudated. Now it will not be said that all France of that time was then a fief of the Capets. And if he is a lord like any other, how does it happen that he forces men who have never held anything from any Robertinian or Capet to take an oath of vassalage to himself, either for themselves or through their ancestors? For all these counts and dukes who consider themselves obliged to respond to his appeals are Carolingians or even Merovingians who have received their benefices and fiefs. It is just because he is not a lord like any other; because he is the king and as such has as vassals those who are the successors of the beneficiaries of the king as a king. He has personal vassals, he has the vassals of his ancestors and he has also those of the Crown. And he has as subjects allotiers who cannot have any "lord" above them, and in all the extent of this kingdom he has never renounced direct claims upon simple freemen, or even upon serfs of the lords. Over all he claims a certain judicial power like that of the judex publicus, at least with respect to the four great crimes. With respect to all of them he has the "heriban" "to which, as we know, all kinds of people must submit." If in certain passing moments these rights seem to weaken, still we must not, when he reasserts himself, reverse the rôles and consider him as attempting to reach individuals "over the head of his vassals," when it is the latter who have tried to break the bond between them and him. And if he is a lord like any other why does everyone respond to his 
appeal against the "Theois," and why have the lords claimed for two centuries the privilege of electing him whom heredity alone would have designated according to feudal law? The truth is that the "idea of the prince" has never disappeared among us. This opinion that the king is something ex officio "by original virtue of his office," and not merely as an infeudant proprietor, has never left the spirit of men.

(2) "By a series of transformations the princely State succeeds . . to the feudal regime... The kings and their legists construe the political and sovereign power of the prince.... The king ceases gradually to be a suzerain who contracts in order to become a master who commands."

If pretty formulae sufficed to make a historian what a historian would Duguit make! "But this suzerainty was property. This power must also be property." And, with the course of Roman law

"which has conceived property as an absolute right, the king, formerly a simple feudal suzerain, has become the unicontested owner of the power to legislate for all, to impose a heavy tax upon all, to render justice to all and to coin money ... The seigniory was patrimonial and the royal power remains patrimonial."

This beautiful structure falls to pieces, as we have seen, before historical facts. If royalty had to develop its forces it did not have to change the formula and the source of its regal rights. ${ }^{8}$

And if here and there in certain authors we find inaccurate expressions, confusion between the public power and what is called the domain, these inaccuracies do not prevent the idea from remaining that which appears from the fourteenth century to the time of Louis XIV. For if Philippe Pot proclaims that royalty is "dignitas non hereditas" and that the "res publica" is the res populi, Louis XIV, in claiming for kings the power to alienate the property of their ecclesiastical or lay subjects is careful to add: "In order to use them as good husbandmen." Duguit is more monarchical than the great king, and that is saying a good deal.

"Like every patrimonial right," continues Duguit, "the power is transferred by hereditary succession." Is it not however, more accurate to say that the heredity of the Crown was the fruit of the practice known under the name of association in the throne continued for two centuries? Now this practice of itself attests the original elective character which it will end by destroying.

\footnotetext{
- To establish the patrimonial character of his powers under the ancient regime Duguit cites Loyseau without noticing that under the latter's pen power or office in property denotes an office which one has as his own instead of having it as a delegate of a superior power and that the expression has nothing in common with property as the element of patrimony.
} 
"Under the pressure of practical necessities ... the principle of the indivisibility of monarchical heredity is introduced." Not at all! Indivisibility commences to appear before heredity under Charlemagne and Louis the Debonair. And when it appears it is under the force not of practical necessity (quite the contrary, for the enormous extent of the Frank domain militates in favor of the divisio regni) but of a theoretical idea, namely, the unanimitas of the revived Roman Empire, an indivisibility conserved even during the partition among the brothers.

The rules of hereditary rights are applied rigorously to reënforce the royal power. The rule of the permanence of the royal power is thus forcefully introduced: The king never dies; the king is dead; long live the king! This was the application pure and simple of the principle of right relating to heredity. And Layseau made of this an application of the rule "Death gives seizin to the living."

I am annoyed for Loyseau's sake (admitting that he did not merely have the idea of showing the practical coincidence of the two rules); but is not the theory of seizin subsequent by at least two centuries to the rule that is presented to us flowing from it. Once invented, it might have been made to serve from a purely legal point of view to legitimately accomplish results in the field of politics, but people did not wait for it to proclaim this perpetuity of power and of the State which Duguit presents as the product of the imagination of jurists. And why has he not been struck by the very form of that adage of which he would make a hereditary rule; since it rejects the idea of death?

(3) And now we come to the Revolution. We are full of admiration for the doctrines of Locke, Rousseau, Montesquieu. Nevertheless, according to Duguit, it is not here a question of admiration whilst spirits are "penetrated by princely and monarchical conceptions." Happily for the unfortunate persons buffeted between these two influences "it happens that by a simple modification of words" the two groups of conceptions may marvellously be

"reconciled. It suffices in fact to substitute the nation for the king. ... We spoke of the sovereignty of the king; we will now say the sovereignty of the nation. That is meaningless; but what does it matter?

These men of the Revolution had rudimentary minds; and thus we "see how the pseudo-idea of national sovereignty happened to be born. "Our finger has been placed upon the evolution which was then accomplished." 10 Is that true?

Now let us briefly compare somewhat the two sovereignties, that of the king and that of the nation:

The first is, in some of the minds of other days, of providential

\footnotetext{
-I Duguit, op. cit., 346.

${ }^{10} \mathrm{Ibid} ., 345$.
} 
origin, even when it is elective, for the meeting of so many wills upon a single name seems due to divine suggestion. Vox populi, vox dei. In the opinion of others it is of customary origin. For all of them it presents nothing contrary to divine right. For the latter it presents nothing contrary to the "laws of the kingdom" which, arising at the same time and from the same source, enjoy the same authority. With the Revolution national sovereignty becomes of natural origin, and limited by nothing, not even by the individual rights which are regarded as powerless against the rights of the community.

During the ancien régime France and the Church of France are from two different points of view merely the same fraction of Christian society, so that, for example, if one does not belong to the latter one cannot belong to the kingdom. As in all that society spiritual and temporal powers are collaborators. And as the Pope is the head of the kingdom of France on its spiritual side the King is the head of the Church of France on its temporal side. Apart from the particular powers which divine unction peculiar to the king of France gives him which confers upon him a quasi-religious character in the lay doctrine at least he is head of the clergy from the point of view of discipline and recruiting, charged with protecting the faith by the punishment of its violators and the surveillance of the press and of sermons, the high administrator of the property of the Church in the kingdom. The Constituent Assembly doubtless is not entirely to break with the old idea and does not suppose that the nation can through its electors reorganize itself from the religious point of view. But no longer will it give to the executive power the rôle of the king in the Church, and it will secularize penal law, marriage, nationality, the entire positive law itself; then the separation comes for the Convention to effect; and after that, if public power recognizes the right of regulating worship in the interest of public peace or defence, if even in time of war it refuses legal protection to the Churches which do not accept certain legal forms, at least it has no longer the idea of directing their clérgy and administering their property.

The "supreme control" was one of the essential attributes of royalty in the last century. With the coming of the Revolution there was no longer any eminent domain for the State.

The king could not only regulate national labor but dispose of it. The right to work is on the contrary for the men of the Revolution one of the imprescriptible attributes of man.

The consequence is that in spite of a current formula there was not merely a transfer to the nation of the sovereignty of the king, but, there was the creation of a new sovereignty, new by its very essence and by its attributes. There is little that can be said as false as that which serves as a basis for the whole system of Duguit. 
"In the doctrine still dominant in France, sovereignty is the commanding power of the State. It is the will of the nation and the nation being organized as a State, it becomes the commanding power of the State and the right to formulate inconditional orders for all individuals in its territory."

"The theory of the personified nation may be summed up as follows: The social collectivity, group, city or nation, is a person distinct from the State and distinct also from the individuals which compose it. It is the titulary of original sovereignty by the mere fact that it is the collectivity and that it is consequently the general will, superior as such to the individual wills. This will is the sovereign will."11

Duguit then discusses all the secondary questions arising out of this notion in so far as concerns, for example, the necessary limitations of sovereignty. After what has gone before must we observe that, so far as we are concerned, all this discussion leads to a false conclusion? In our opinion the collectivity is not a person in the sense in which Duguit uses the expression; it therefore cannot have a will; a general will is not necessarily superior to the individual wills, even in small number; moreover, in fact even the will of the majority cannot exist legally under the majority of constitutions, having no official means of being formed or of formulating itself and making itself known.

The idea of sovereignty seems to us infinitely more simple. Being members of a particular national group, we cherish it and desire its present and future prosperity. It is our wish that order reign in the group, that man may develop himself within it with facility, that he find therein satisfaction for all the needs of the collective life, including, for those who adopt our ideas, those aspirations for justice, goodness, etc., which we consider as the natural guides of man. This is merely wishing that all persons in the territory shall observe the discipline necessary to order, liberty and progress and shall accept the burdens which collective life necessarily imposes; that even outside this territory, whoever wishes to remain a member of the group, enjoy its protection and reënter its soil as his home shall also bear his part of certain obligations. This is merely wishing that there shall be in the bosom of the collectivity men who can command, govern, etc., without their decisions having to be subjected to the judgment of every citizen; that they shall command not according to our point of view, for there is nothing that authorizes us to assume the rôle of governors, but in the best material and moral interests of all of us and of the group, as servants of those interests, in the name of the will which is ours to accept the sacrifice necessary for those interests; that these men finally be those who ought to love the group

$u_{2}$ Duguit, op. cit., 57. 
and who can share and understand its needs, and not be the tools of foreign powers, indifferent if not hostile and incompetent.

This will of ours may meet the opposition of contrary wills. If they attack the grouping itself, by seeking its dissolution because they do not care for it, they may also be legitimate. There is perforce then a conflict between them and us because we cannot both live side by side without accepting the same discipline. This conflict is in the class of those whose regulation does not belong to law. But if the opposition proceeds from men who refuse to assume the necessary common burdens while pretending to welcome the benefits of the common life, the cerebral construction which is more and more characteristic of man forces us to say: "Ubi emolumentum ibi et onus esse debet." And our will is superior, as we have seen, by nature to these anti-natural and unjust desires. Our will becomes a right. If I were alone in possessing this right as against millions of these illegitimate interests, that would practically signify nothing. It would none the less be a right and by itself alone it would furnish a legal basis for institutions which compel the government of the group and its territory in conformity with right. As a matter of fact this is not what ordinarily happens where there is a "nation" in the common acceptation of the word and consequently a moral unity and a wish to remain together. This will of mine is also that of all or nearly all my fellow citizens. If it does not prevail among all, express and conscious, it exists at least in the state of acceptance of the status quo. The absence of any contrary will is equivalent here to unanimity in the will to accept, so that one may properly say, it is the national will. But if there exist rebellious wills in small number the expression does not become inaccurate. In both cases the legitimacy of the existing power rests indeed on this general will, but, correctly, it would rest in case of need upon a single individual will.

National sovereignty is not then in our opinion, either a power to command or the general will, but the right of each member of the nation to have in it a power capable of governing it and its territory to the best of the national interests without having to seek orders from outside. Or if one wishes, it is according to the individual right of each of us the right of the group to have its interests served by all in the measure necessary, under the command of an autonomous government, itself, the servant of these interests.

This notion of sovereignty proceeding from individual right furnishes, with as much accuracy as any other, the solution of all those important questions to which the theory of the State gives rise.

The only question open to debate is to determine how governments ought to be recruited. No one has the right to appoint them in his own interest; and consequently by natural law the only wills which are legitimate are those which in their tendency to some particular method of recruiting have as their aim its adaptability best to furnish 
the most national, the most competent, and the most authoritative government possible. But among these wills (wills in the true sense of the word or adhesions or acquiescence in the status quo), wills unequal doubtless in their rational value but equal in law, there is no other hierarchization than that of the law of numbers.

In the notion which Duguit ascribes to individualism" the will of the State is superior to other wills located in the territory."

"It was understood that this sovereignty of the State could not be in fact an absolute and unlimited sovereignty; and, moreover, if it creates the law how can it be limited by the law? ... The individualist doctrine once abandoned there remains only the idea of the autolimitation of the State."12

In our opinion, the answer is more simple and results from the observations already stated: National sovereignty is not absolutefirst, because our individual rights on which it rests cannot require the violation of certain other great individual rights like liberty of conscience or honor; second, because if rights of the least inclusiveness, such as the right to life or property can be compromised or infringed it would still be necessary that it impose an equality of sacrifice or risk upon all the people; otherwise it would violate the rule dictated by conscience: ubi emolumentum; and third, because if we have the right to impose upon each other burdens necessitated by the group life, our right, clear and precise when it concerns necessities apparent on the part of all or nearly all of us, loses in clearness and precision as we have seen with the number of those who think as we do or with the gravity of the question under consideration and consequently the importance of the interest for which we take up arms.

All that can be said is that in fact the State is impossible if the slightest acts of power must demand the adhesion of all minds and if we do not give up the idea that in principle these acts have a real authority by the mere fact that they are acts of power. There are blunders and injustices which it will be in our legitimate interest and part of our duty to accept, because the maintenance of the State even with them is worth more than victory over them with destruction or weakening of the State. In any case we need not speak of autolimitation nor anything similar for the State, for the excellent reason that it arises quite as limited as the individual wills which serve as the raison d'être of its power.

"In the common theory which considers the State as a sovereign personality it becomes peculiarly difficult to explain and admit the obligatory character of the contracts entered into by the State. If in fact the State has sovereignty and if it is a commanding power creating the law .... it always retains that character...; the

I Duguit, op. cit., 613. 
relation which arises between the State and another entity can never be a relation of two contractors and will always be a relation of superior to inferior. The logical result is that international conventions are not obligatory, that there is no international law, that the relations between all nations must be left to force, and that, in public internal law contracts of the State are obligatory upon the individual who assents to them but not upon the State."

"It appears evident that the distinction of a dual personality of the State ... of a personality of public law belonging to the titulary State of the Herrschaft and of a personality of private law belonging to the State as a fiscus explains nothing at all. This dual personality of the State must be proved. Now, if it seems possible to us to demonstrate that the State constitutes a person a fortiori it is impossible to establish that it constitutes two persons. Here is a mystery of duality of which it is impossible to give an explanation."

Let us overlook this slight pleasantry which doubtless makes no scientific claims, especially coming from a man for whom there exists no difference between public law and private law. Duguit is here visibly prompted by the malign pleasure of placing obstacles in the road of individualism. Is the source of the reasoning worth more than the form? It does not seem so to us; for the State is not a power of commanding. It is a legal person having its personality from the law, as we have seen, and that law has power through the right of individuals who, desiring the maintenance and prosperity of their group, wish thereby that it be served from the internal, political point of view and from the international political point of view and accept consequently in advance the burdens necessary for its prosperity, and among them the engagements of every kind contracted by the governing authorities. The mystery for us is that anyone should find a mystery in it.

"The doctrine of individual rights is indeed powerless to support positive obligations of the State."13 We might answer (as Duguit himself answers those who say to him "But then you are going to suppress the State and public law"): So much the worse for the positive obligations if they can only be founded on false bases. "If the individual has rights because he is a man he can only have the rights which he has by nature and according to the expression of the eighteenth century: he has the rights of natural man and no more. The right to social assistance is a social right. In the pure individualist doctrine man cannot impose it on the State."14 Here again, has Duguit understood individualism?

It is surely easy to affirm in morals the duty of those "privileged by. fortune" to assist those less fortunate and to place them in a position to educate themselves.

It is more difficult, impossible even in our opinion, to affirm the right

${ }^{28}$ Ibid., 15. $\quad$ "Ibid. 
of the disinherited to this assistance and to free education, which is a form of it. ${ }^{15}$

But with positive law, this right will arise if the State accepts for itself this duty of social assistance and organizes it, for its laws may then be invoked by all members of the group. The whole question is then of determining whether, this being so, governments would permit themselves to do anything arbitrary in excess of their powers, or, in other words, if each of us has an individual right that all in the group shall make sacrifices to relieve individual misery and spread education. If they have, governments must satisfy this right.

The question thus posited is a matter of appreciation, but we may ask a priori "Why not?" Has not each of us, either for his own good or for that of the group whose prosperity he wishes, an interest that within that group advantages be drawn from all human forces and also that the power shall make for us a sane and habitable milieu in which one may enjoy without bitterness the comfort that one may have reached, in which one may not be troubled in his enjoyment by the idea of the distress of neighbors, in which there shall not exist entire classes unnecessarily harboring grievances, etc. That interest is evident, and if it does not clash with others naturally superior or even equal but more numerous, it will be the right. Are there interests naturally superior? I know of none. Are there equal interests? Possibly. In much greater number? That is a question of fact whose solution will vary from nation to nation with fortunes and mentalities, with what has previously been acquired in the way of civilization, etc.

It seems to me that we can close our claims here. We have done enough to show that in all the important problems the pretended dogmas attributed to individualism, some of them are strange ideas which do not belong to any French doctrine, and others, opinions perhaps acceptable but personal to some particular individualist who does not thereby bind "the School." The brief gesture by which both of them are swept aside by our opponents leaves our doctrine unimpaired. If no other blemishes are found in it it will flourish for a long time. What it may be sought to establish in its place may well be more fragile.

.${ }^{18}$ We examined this question some years ago and others with it in a little essay published in I908 under the title "Solidarism et Quasi-contrat social." Prepared as a university address and obliged consequently to impose but a minimum of burden upon the general public which came to hear it, this study could not be taken seriously and will never be included among learned works. Nevertheless, if perchance it should fall into the hands of some sociologist desirous of learning everything that has been seriously written upon these problems, I would ask that he be kind enough not to condemn it on its appearance alone. It expresses matured ideas, and rewritten as we should like, not merely revised but thoroughly rewritten, it might perhaps acquire as much consistency as others which are called learned works. 